GRISEOFULVIN TREATMENT OF ACUTE CATTLE RINGWORM INFECTIONS

\section{IN MAN -}

BY

THOMAS COCHRANE, M.D., F.R.F.P.S.

Consultant Dermatologist, Ayr County Area

AND

ADAM TULIETT, M.B., Ch.B.

Clinical Assistant, Heathfield Hospital, Ayr

The discovery of an efficient systemic antibiotic for use against acute and chronic fungus infections of the skin has long been awaited by dermatologists. With griseofulvin it now seems to be at hand.

Gentles (1958) reported the successful oral treatment of trichophyton and microsporon infections in guineapigs with griseofulvin, and Lauder and O'Sullivan (1958) found it effective in calves with Trichophyton verrucosum ringworm

Williams, Marten, and Sarkany (1958) published a preliminary report of the use of griseofulvin in nine cases of Trichophyton rubrum infection and one case of Microsporon audouini infection of the scalp. They considered that the results supported the hope that griseofulvin might be of therapeutic value.

During the first three months of 1959 this antibiotic has been used to treat fungus infections in the skin clinics in Ayrshire. As this is an agricultural area the incidence of acute cattle ringworm infections of the skin is high. This short paper has been prompted by the very encouraging results of treatment with griseofulvin in these cases.

The results of treatment in 16 cases of acute inflammatory cattle ringworm are summarized in Table I. The acute inflammatory lesions were essentially kerions -nodular, boggy, exudative circumscribed tumours which were studded with pustules. Frequently the lesions were crusted and foul-smelling. The neighbouring lymphatic glands were enlarged and tender, and often the patient had a mild pyrexia and general malaise. In addition to this inflammatory type of lesion, several cases had acute active annular areas of ringworm.

In addition to a vesicular border, scaling, redness, and slight infiltration were present throughout these lesions,

TABLE I

\begin{tabular}{|c|c|c|c|c|c|c|c|c|c|c|}
\hline $\begin{array}{l}\text { Case } \\
\text { No. }\end{array}$ & $\begin{array}{l}A g \\
\text { and }\end{array}$ & Sex & Site & & $\underset{\text { Type }}{\text { Clinical }}$ & $\begin{array}{l}\text { Duration } \\
\text { in Weeks }\end{array}$ & $\begin{array}{l}\text { Daily } \\
\text { Dose }\end{array}$ & $\begin{array}{l}\text { Duration of } \\
\text { Treatment }\end{array}$ & $\begin{array}{c}\text { Time to } \\
\text { Clinical Cure }\end{array}$ & Remaiks \\
\hline 1 & 45 & $\mathbf{M}$ & Beard & . & Kerions & 2\{ & $\begin{array}{l}2 \mathrm{~g} . \\
1, "\end{array}$ & $\begin{array}{l}1 \text { week } \\
3 \text { weeks }\end{array}$ & 3 weeks & Culture 3rd week negative \\
\hline 3 & 6 & $\mathbf{F}$ & Nose, forehead & . & Annular & 3 & $\begin{array}{l}1, " \\
1 \text {.7’" }\end{array}$ & 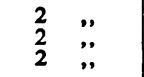 & 2 " & $\begin{array}{l}\text { Scales negative on direct examination. } \\
\text { Erythema only after two weeks }\end{array}$ \\
\hline $\mathbf{s}$ & 20 & $\mathbf{M}$ & Beard, neck & . & $"$ & 2 & $\begin{array}{l}2,3 ", \\
1 ., "\end{array}$ & $\begin{array}{l}1 \text { week } \\
1 \text { weeks }\end{array}$ & 3 & \\
\hline 6 & 42 & $\mathbf{M}$ & Beard, right foree & arm & $"$ & \{ & 2, & $\begin{array}{l}1 \text { week } \\
3 \text { weeks }\end{array}$ & $2 \frac{1}{2}$, & Hairs-negative, direct examination \\
\hline 7 & 26 & $\mathbf{F}$ & Eyebrow, neck, ch & heek & $\begin{array}{l}\text { Kerion, } \\
\text { annular }\end{array}$ & 2\{ & $1 \cdot 5$, & $\begin{array}{l}10 \text { days } \\
3 \text { weeks }\end{array}$ & $\begin{array}{ll}3 & , "\end{array}$ & Epidermal scales clear after three weeks \\
\hline 8 & 37 & $\mathbf{M}$ & Neck & $\cdots$ & Kerions & & 1.5, & $\begin{array}{l}1 \text { week } \\
3 \text { weeks }\end{array}$ & & \\
\hline 11 & 16 & $\begin{array}{l}\mathbf{M} \\
\mathbf{M}\end{array}$ & $\begin{array}{l}\text { Scalp, right foree } \\
\text { Beard }\end{array}$ & arm & $\begin{array}{c}\text { Kerions } \\
\quad "\end{array}$ & $\begin{array}{l}4 \\
3\end{array}$ & 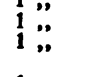 & $4 "$ & 2-3", & $\begin{array}{l}\text { No relapse three weeks after treatment } \\
\text { No relapse three weeks later. Hairs } \\
\text { negative on direct examination }\end{array}$ \\
\hline 13 & 10 & $\mathbf{M}$ & Scalp $\quad \ldots$ & . & " & 2 & o.73 & $2 \quad \ddot{2}$ & 3 " & $\begin{array}{l}\text { No recurrence. Hairs negative on direct } \\
\text { examination }\end{array}$ \\
\hline 14 & 18 & $\mathbf{F}$ & Chin, cheeks & $\cdots$ & Annular & & $1, "$ & 3 & 12-15 days & Slight erythema, but direct examination \\
\hline 15 & 12 & $\mathbf{F}$ & $\begin{array}{l}\text { Right palm and } \\
\text { fingers }\end{array}$ & & " & 8 & 1 & " & 2-3 weeks & $\begin{array}{l}\text { Clinically normal skin after three weeks. } \\
\text { Treatment continues }\end{array}$ \\
\hline 16 & 23 & $\mathbf{M}$ & Beard, chest & .. & $\begin{array}{l}\text { Kerions, } \\
\text { annular }\end{array}$ & 2 & 1 , & $"$ & 2-3 , , & $\begin{array}{l}\text { Chest cleared in } 12 \text { days. Direct exam- } \\
\text { ination negative. Treatment continues }\end{array}$ \\
\hline
\end{tabular}

TABLE II

\begin{tabular}{|c|c|c|c|c|c|c|c|c|c|c|}
\hline $\begin{array}{l}\text { Caso } \\
\text { No. }\end{array}$ & \multicolumn{2}{|c|}{$\begin{array}{c}\text { Age } \\
\text { and Sex }\end{array}$} & \multicolumn{3}{|c|}{ Site } & Duration & Culture & $\begin{array}{l}\text { Daily } \\
\text { Dose }\end{array}$ & $\begin{array}{l}\text { Duration of } \\
\text { Treatment }\end{array}$ & Renuarks \\
\hline 1 & 55 & $\mathbf{F}$ & Finger-nails & . & .. & 20 years & T. rubrum & $\begin{array}{l}2 \mathrm{~g} . \\
1 \cdot 5\end{array}$ & 2 weeks & $\begin{array}{l}\text { Only distal } 1 / 3 \text { now affected. Treatment } \\
\text { continues }\end{array}$ \\
\hline 2 & 8 & $\mathbf{M}$ & Scalp .. & . & . & 4 months & T. schoenleini & $1 "$, & $6 "$ & Wood light negative. Head shaved. 2nd \\
\hline 3 & 14 & $\mathbf{M}$ & Right palm, & nails & . & & T. rubrum & 2 & $\begin{array}{l}4 \\
4\end{array}$ & $\begin{array}{l}\text { Hands now normal. Distal } 1 / 3 \text { nails only } \\
\text { affected }\end{array}$ \\
\hline $\begin{array}{l}4 \\
5\end{array}$ & $\begin{array}{r}38 \\
9\end{array}$ & $\underset{\mathbf{M}}{\mathbf{F}}$ & $\begin{array}{l}\text { Finger-nails } \\
\text { Scalp }\end{array}$ & $\begin{array}{l}\cdots \\
\cdots\end{array}$ & $\because$ & $\begin{array}{l}3 \text { years } \\
9 \text { months }\end{array}$ & M. audoüint & $1 "$ & $8 "$, & $\begin{array}{l}\text { Almost well. Treatment continues } \\
\text { Wood light negative after three weeks. } \\
\text { Head clipped }\end{array}$ \\
\hline 6 & 28 & $\mathbf{M}$ & Left paim & .. & .. & 2 years & T. rubrum & $2, "$ & 2 & $\begin{array}{l}\text { No irritation. Direct examination now } \\
\text { negative. Treatment continues }\end{array}$ \\
\hline 7 & 30 & $\mathbf{M}$ & Right , & . & .. & 5 & $" \quad "$ & 1 ." & $6 "$ & No itch. Scaling now clear. Clinically \\
\hline 8 & 45 & $\mathbf{M}$ & Feet $\quad \ldots$ & . & . & 8 , & $", \quad$, & 1, & 3 , & No irritation. No fresh vesicles three \\
\hline 9 & 10 & $\mathbf{M}$ & Scalp .. & . & .. & 6 months & $\begin{array}{l}\text { Wood light positive. } \\
\text { No culture }\end{array}$ & 1 ," & 4 ." & $\begin{array}{l}\text { Scalp shaved after two weeks. Wood } \\
\text { light negative }\end{array}$ \\
\hline
\end{tabular}


and there was little evidence of central clearing as is common in the classical tinea circinata. Occasionally superficial pustules were present in the centre of the lesions.

All of the 16 cases had been in contact with cattle or farm buildings, and in every case culture from hairs or epidermal scrapings produced Trichophyton verrucosum. At the start of this series an initial daily dose of $2 \mathrm{~g}$. of griseofulvin was given for one week and then reduced as the clinical appearance of the lesion responded to treatment. In subsequent cases, however, treatment was started and continued with $1 \mathrm{~g}$. daily-with little or no effect on the duration of clinical involution of the active lesions. No local treatment was used apart from $1 / 4,000$ mercury perchloride lotion to the crusted and foul. smelling lesions and mechanical removal of all loose hairs in the area.

Routine blood examinations were done weekly on every patient, but no abnormality was detected. Liverfunction tests were also carried out on several patients, but again these were normal.

Two patients complained of mild gastro-intestinal upset when taking $2 \mathrm{~g}$. of the antibiotic daily, but this disappeared when the dose was reduced to $1 \mathrm{~g}$. daily.

To compare the response to griseofulvin therapy four cases of cattle ringworm infection were kept on routine standard treatment. Three of these had acute inflammatory lesions of the beard and scalp and one had a widespread annular ringworm of the face, neck, and shoulders. Treatment consisted in removing loose hairs and using hot boric lint fomentations, antiseptic lotions, and fungicidal ointments. In the acute inflammatory cases treatment was continued for nine and ten weeks before resolution took place, while, in the case of annular ringworm, treatment was required for six weeks before fresh lesions ceased to appear. This has been our experience in the treatment of these cases over the past five years in Ayrshire.

The most noticeable difference, in our opinion, between the cases treated routinely and those treated with griseofulvin, apart from the duration of clinical involution, was the rapid disappearance of general malaise, pain, and discomfort in the cases treated with the antibiotic. In nearly all cases this had completely gone after one week of treatment. Another difference found was in the response of the early satellite lesions. In the griseofulvin-treated cases these did not develop further, as was the case in the routinely treated patients, but simply settled down with a rapid disappearance of all inflammatory signs.

In addition to these cases of acute cattle ringworm infections we have also started treatment of several other types of ringworm infections with griseofulvin. The results are summarized in Table II. In our opinion these results show that griseofulvin is an antibiotic of great value in the treatment of a large variety of fungus infections of the skin. It would appear to open up a new era in the treatment of human ringworm infection, and will banish for ever, we hope, the necessity to epilate a scalp or beard by $x$ rays.

\section{Comments}

The new systemic antibiotic griseofulvin now seems to be the treatment of choice in acute cattle ringworm infections of the human skin.
A daily dose of $1 \mathrm{~g}$. seems to be adequate at present. However, the minimum effective dose and the optimum dose of the drug have yet to be established. The duration of the infection does not seem to have any bearing on the response to treatment.

In acute inflammatory ringworm of the beard and scalp the duration of treatment has been shortened by approximately six weeks. The pain and discomfort in the lesions and the general toxicity of the patient clear much more rapidly with griseofulvin. The duration of treatment will depend on the type of infection and tissue involved.

In the present series of cases, only mild side-effects were seen in two patients. In prolonged treatment, however, as, for example, in tinea of the nails, routine blood examination is still thought advisable, although it would seem to be unnecessary when the antibiotic is given only for short periods.

We are indebted to the staff of the department of medical mycology, University of Glasgow, for their considerable help in supplying the culture reports in this series of cases. The griseofulvin used in this series was supplied by Glaxo Laboratories Ltd.

\section{REFERENCES}

Gentles, J. C. (1958). Nature (Lond.), 182, 476. Lauder, I. M., and O'Sullivan, J. G. (1958). Vet. Rec., 70, 949. Williams, D. I., Marten, R. H., and Sarkany, I. (1958). Lancet, 2. 1212 .

\section{Medical Memoranda}

\section{Calcified Suluphrenic Abscess}

Amoebic abscesses of the liver are fairly common in Singapore, and usually present with pain and tenderness over the right lower chest or hypochondrium, fever, and leucocytosis. The case reported here was diagnosed and treated as an amoebic liver abscess, the unusual feature being the massive calcification of the abscess. An almost identical radiological finding was reported by Bruce (1957) in a young Englishman who was symptomless but gave a past history of amoebic dysentery. Bruce concluded that his patient had a calcified amoebic liver abscess, but, because there were no symptoms, did not treat him. Necropsy of the present case, however, showed that the calcified abscess was in fact subphrenic and not in the liver.

\section{CASE REPORT}

A male Chinese cock aged 57 was admitted to the General Hospital, Singapore, with a five-days history of continuous pain in the right hypochondrium, aggravated by pressure and occasionally radiating to his right back and right shoulder ; this was associated with anorexia, loss of weight, and mild fever. He had no cough, jaundice, or recent diarrhoea. He remembered having had similar pain in China at the age of 17 years, following an attack of diarrhoea, and eventually recovering without medical treatment.

On examination he was pale, thin, and wasted, with a temperature of $100.4^{\circ} \mathrm{F}$. $\left(38^{\circ}\right.$ C. $)$; he was not jaundiced. The right lower chest was bulging anteriorly and laterally, and there was tenderness over the intercostal spaces in this 